\title{
Squaring the circle? Collective and distributive effects of United Nations Security Council reform
}

\author{
Madeleine O. Hosli • Rebecca Moody • \\ Bryan O'Donovan • Serguei Kaniovski • \\ Anna C. H. Little
}

Received: 27 December 2009 / Revised: 10 January 2011 /Accepted: 8 February 2011 /

Published online: 29 March 2011

(C) The Author(s) 2011. This article is published with open access at Springerlink.com

\begin{abstract}
Changing the composition and voting system of the Security Council, in an effort to increase the institution's global legitimacy, is proving to be one of the most difficult hurdles to overcome for the global community of states represented in the United Nations (UN). This paper demonstrates that due to institutional hurdles, it is considerably more difficult today than it was in the early years of the UN to reach a winning coalition in the General Assembly to secure Security Council reform. In addition, the paper analyzes the effects that adapted patterns of voting, as prescribed by recent reform proposals, would have on the distribution of power among UN member states in the Security Council and on the probability that this institution can form a winning coalition, i.e., reach decisions. Our power and decision capacity computations are based on (modified) Penrose-Banzhaf-Coleman measures.
\end{abstract}

Keywords United Nations Security Council • United Nations General Assembly •

Electronic supplementary material The online version of this article (doi:10.1007/s11558-011-9101-1) contains supplementary material, which is available to authorized users.

M. O. Hosli $(\bowtie) \cdot$ B. O’Donovan

Department of Political Science, Leiden University, P.O. Box 9555, 2300 RB Leiden, NL, The Netherlands

e-mail: hosli@fsw.leidenuniv.nl

B. O’Donovan

e-mail: bryan_od@hotmail.com

R. Moody

Department of Public Administration, Erasmus University Rotterdam, Rotterdam, The Netherlands e-mail: moody@fsw.eur.nl

S. Kaniovski

Austrian Institute of Economic Research (WIFO), Vienna, Austria

e-mail: Serguei.Kaniovski@wifo.ac.at

A. C. H. Little

Pragmora International Peace Organization, Toronto, Canada

e-mail: anna.little@sympatico.ca 
Decision-making $\cdot$ Distribution of votes $\cdot$ Coalition-formation

\section{Introduction}

Generally, actor preferences, combined with voting rules, strongly shape an organization's policy outcomes. Similarly, the institutional foundations of international organizations (IOs), and their respective decision-making procedures, crucially affect actions taken by the collectivity of their members. For many years, efforts to change the composition and decision-making procedures of the Security Council have remained stuck in limbo, due to conflicting state interests, in spite of the fact that most global actors share the perception that adaptations are needed, and do favor change.

What proposals have been made so far to reform the UN Security Council and what would be their implications in terms of the capacity of this institution to take decisions and on the distribution of influence among its member states? Can impasses for UN Security Council reform be overcome? Are the obstacles to reform of a purely political nature, or could they partially be rooted in the UN's institutional provisions? A solution will need to strike delicate balances between what is desirable and what is achievable, in order to find support from a large number of governments. In general terms, Martin Rochester has argued that UN reform essentially needs "a dominant coalition of states able and willing to steer the system in a manner that offers incentives for others to follow" (1993: 223). Proposals made in preparation for the September 2005 General Assembly meeting in New York aimed to achieve just this, but still could not find the support needed to effect change.

Although there seems to be considerable consent among UN member states that Security Council reform is needed, agreement on specific options for change has proved to be difficult to achieve. In the UN, non-charter reforms are much easier to achieve than are amendments to the UN Charter itself. However, each kind of institutional reform always implies a redistribution of benefits and losses for an organization's entities, either in terms of a reallocation of decision-making power orand usually connected to this - a re-orientation of the organization's policy perspectives. Institutional structures themselves, however, may be an important cause for the difficulty to achieve reform.

This paper focuses on decision rules in the United Nations (UN), notably in the Security Council. It explores how decision procedures, by their institutional properties, favor certain state preferences. Another part of the inquiry in this paper concerns the effectiveness of decision-making, measured by the likelihood that an organization reaches decisions. Accordingly, the paper compares the relative ease with which decisions were made, on the basis of institutional provisions, in the early days of the UN as compared to the present. In addition, the paper analyzes the flexibility of institutional structures regarding their capacity for change-a topic particularly salient regarding general prospects for Security Council reform.

The structure of the paper is as follows. Section two describes the origins and objectives of the Security Council and discusses past and present decision-making rules of this institution. Section three provides information on the way 'decision capacity' and 'relative voting power' will be measured in this paper, using decision 
capacity computations based on (modified) Penrose-Banzhaf-Coleman measures. In section four, based on this methodology, recent proposals for Security Council reform are evaluated. The final section summarizes the main findings and concludes this paper.

\section{The Security Council: Membership and Voting}

The overall objective underlying the establishment of the UN Security Council was to "save succeeding generations from the scourge of war" (Preamble to the UN Charter). With the devastating effects of World War II still fresh in their minds, the Great Powers, however, made clear that such an institution could not exist without veto power being attributed to themselves. The legitimacy they claimed derived from having prevailed as victors in the war, and thus being the most suitable to guarantee future international peace and stability (Russett et al. 1997: 156). The negotiations on the foundation of the Security Council resulted in the formulation of article 23.1 of the UN Charter. After the 1963 amendment, with which the size of the Security Council was increased, its contents were as follows:

"The Security Council shall consist of fifteen Members of the United Nations. The Republic of China, France, the Union of Soviet Socialist Republics, the United Kingdom of Great Britain and Northern Ireland, and the United States of America shall be permanent members of the Security Council. The General Assembly shall elect the other Members of the United Nations to be non-permanent members of the Security Council, due regard being specially paid, in the first instance to the contribution of Members of the United Nations to the maintenance of international peace and security and to the other purposes of the Organization, and also to equitable geographical distribution."

Before this revision, the Security Council had encompassed five permanent and six non-permanent member states. After the 1963 Charter amendment, the composition of the Security Council was never adapted again, in spite of the presentation of a variety of proposals for reform.

However, changes to the fundamental structure of the Council require high voting thresholds to be passed, although some have described them as modest in comparison with other international organizations (Voeten, 2005: 186). Nevertheless it is the mark of the 1963 amendment, and those who were the driving force behind its adoption, that enough support was gained to make the necessary reforms. As Russett, O'Neill and Sutterlin point out, given the institutional barriers to reform of the UN's organs, any proposal for change needs to strike careful (and intertwined) balances, such as "the balance between practicality and vision," the balance "between power (or effectiveness) and legitimacy (or justice)," and, perhaps most importantly, the "balance of interests" (1997: 17-26).

However, the rebalanced Council created by the 1963 amendment could not outlast the changing nature of the world, and critiques are now rather widespread that the current composition of the Security Council no longer reflects the geopolitical, economic and demographic realities of the present international system. Accordingly, much attention has focused on proposals aiming to render the Security Council more representative of modern UN membership. Particularly, the veto 
power of the P-5 has come under criticism, leading some to claim that the persistence of the veto precludes the Council from being able to "symbolize democracy" (Sutterlin 2005: 179).

Article 27 of the UN Charter presents the voting rules of the Security Council:

1. "Each member of the Security Council shall have one vote.

2. Decisions of the Security Council on procedural matters shall be made by an affirmative vote of nine members. On procedural matters there exists no right of veto.

3. Decisions of the Security Council on all other matters shall be made by an affirmative vote of nine members including the concurring votes of the permanent members; provided that, in decisions under Chapter VI, and under paragraph 3 of Article 52, a party to a dispute shall abstain from voting."

Hence, each Security Council member holds one vote and decisions on procedural issues can be taken on the basis of a qualified majority of affirmative votes cast by nine out of the total of fifteen members (whereas a simple majority would be constituted by eight out of fifteen votes). However, decisions on nonprocedural issues require an affirmative vote by nine members of the Security Council, including the P-5. These issues concern some of the most important actions to be taken by the Security Council, including resolutions to establish peacekeeping operations and the possible application of coercive measures against a UN member state.

How are abstentions in the Security Council treated formally? Generally, two basic forms of abstentions can be distinguished: obligatory abstention as referred to in article 52, paragraph 3 of the UN Charter (implying that members party to a dispute shall abstain from voting), and the more common form of voluntary abstention (Bailey, 1969: 63-75). However, obligatory abstention has so far never occurred in practice since UN states that were party to a conflict could argue that the case at hand was not actually a 'dispute', but rather a 'situation', and in this way escape the need for obligatory abstention.

Voluntary abstention is used quite frequently in practice. According to the UN Charter, a decision of the Security Council on non-procedural issues requires an affirmative vote by nine members, including the 'concurring' votes of the P-5. It is not entirely straightforward, however, what 'concurring' signifies in practice. At the UN constituting conference in San Francisco, abstention was understood to have a similar effect to a negative vote. With a precedent set earlier by the U.S.S.R, however, the effect of abstaining is no longer interpreted in practice as being equal to a negative vote, but rather seen as a non-affirmative vote. Hence, the concurring votes of the P-5 are interpreted as affirmative votes of the permanent members of the Security Council present and casting a vote. Abstentions, in this sense, are less consequential than are negative votes.

Non-permanent members of the Security Council are elected for two-year terms, with five members being replaced every year. Representation has traditionally been determined by regional affiliation: of the non-permanent members, three are usually from Africa, two from Asia, one from Eastern Europe, two from Latin America, and two from Western Europe and other states-Australia, Canada and New Zealand (Baehr and Gordenker, 1999: 25). Patterns of representation for non-permanent 
members have also been discussed intensively in the framework of several recent proposals for Security Council reform.

The attribution of veto power to the P-5, compared to non-permanent members, gives this group of states high leverage within the Security Council. There are obvious rewards to being a 'mere' non-permanent member, such as prestige, the opportunity to voice a country's opinion, and intermingling with the chief power-brokers in global politics, but real voting power is not included in the perks (Russett, 2005: 160). According to Kuziemko and Werker (2006), nonpermanent UN Security Council membership may also increase U.S. foreign aid and development aid a country receives, notably through UN programs in which the US is influential (e.g., UNICEF). According to the authors, on average, aid received by a country from the United States, for example, increases by $59 \%$ and aid received by the UN by $8 \%$ when it rotates onto the Security Council. As Dreher et al. (2009a) have demonstrated, temporary membership of the UN Security Council increases the probability of a country obtaining World Bank projects (although the size of the loans is not affected). Similarly, non-permanent members of the Security Council participate more frequently in IMF programs, and have fewer conditions attached to their loans (Dreher et al. 2009b). According to Bueno de Mesquita and Smith (2010), however, due to the fact that temporary UN Security Council nations receive increased aid flows - by the U.S., but also by institutions such as the UNDP, the IMF and the World Bank - they experience a contraction of their economy relative to nations not elected to this institution. In addition, freedom of the press tends to be constrained. These effects occur during their non-permanent membership and the phase just afterwards and are strongest for nondemocratic nations.

Clearly, non-permanent membership of the UN Security Council has some advantages, but also disadvantages and non-permanent members are less influential in decision-making in the Security Council than are the permanent members. Some have gone so far as to say that in terms of voting, the veto effectively means there are only five members of the Security Council (O’Neill, 1997: 63). How much stronger is their formal influence - apart from the political leverage veto power may generate - as measured in quantitative terms, allowing for the fact that member states' preferences may be similar? What is the likelihood that resolutions can pass at all in the Security Council in its current form, versus in the forms suggested in different reform proposals? How do different assumptions regarding the homogeneity of actor preferences influence these results?

\section{Measuring Relative Voting Power and Decision Probability}

How can relative influence be measured in accordance with specific voting schemes? When analyzing influence within the UN Security Council, it is helpful to see how weighted voting schemes may translate into relative a priori voting power of member states, and how decision rules influence the capacity of these institutions to make decisions, ceteris paribus. Power indices can be used to explore this topic. We compute the Penrose (1946)-Banzhaf (1965) measure of voting power for the members of the UN Security Council and the Coleman (1971) measure of a 
collectivity to act, but check for effects of alternative assumptions regarding the likelihood that specific coalitions form. ${ }^{1}$

In general, power indices aim to capture the effects of the institutional framework of an organization. They aspire to provide results that remain valid over a longer period of time, and account for the range of different issues to be decided upon by the institution and accordingly, the potentially changing patterns of collaboration among member states. Effects of reform, for example the modifications suggested for the Security Council, can also be assessed with these tools.

The 'flexibility of constitutional design' and 'decision probability' were studied in the seminal work of Buchanan and Tullock (1962). In general terms, increasing the voting threshold within a committee, such as moving from the simple majority to a two-thirds rule, lowers the probability that winning coalitions will form, leading to a decrease in decision probability. Decision probability will here be measured as the likelihood that a randomly selected coalition among member states can form a winning coalition. When no restrictions on coalition-formation are introduced according to the Independent Coalition Culture (ICC) principle, a useful measurement of decision probability is Coleman's index of the power of a collectivity to act (Coleman 1971). ${ }^{2}$

Straffin (1977) has shown that classic power indices reflect specific probabilistic assumptions concerning the votes cast within committees. The Penrose-BanzhafColeman measures assume that each committee member casts an affirmative vote independently from all other members, with the probability of voting 'yes' of 0.5 . The assumption that all voting outcomes are equally probable is consistent with the binomial model of voting in which each vote has an equal probability of being for or against a motion, and all votes are independent. One consequence is that all conceivable arrangements of votes, or coalitions, are equally likely. ${ }^{3}$

The key probabilistic assumption underlying the Penrose-Banzhaf measure is that the votes are independent random variables. This assumption is implausibly strong,

\footnotetext{
${ }^{1}$ In addition to this, in the online appendix to this paper which is provided on the webpage of this journal, we present calculations based on the Shapley-Shubik index (Shapley and Shubik 1954). While in most voting games the Shapley-Shubik powers are very close to the Penrose-Banzhaf powers, in subsequent calculations, compared to estimates based on the (normalized) Penrose-Banzhaf index, the Shapley-Shubik index tends to provide higher voting power assessments for members holding veto power than for UN members other than the P-5. However, the Shapley-Shubik index has been criticized by some authors, including, on theoretical grounds, by Felsenthal and Machover (1998) and in terms of its empirical properties, by Leech (2002b).

${ }^{2}$ For applications of this index to the European Union, e.g., see König and Bräuninger (1997), Leech (2002a) or Hosli and Machover (2004).

${ }^{3}$ This assumption seems to be conflicting with actual voting behavior in an institution such as the UN Security Council: clearly, "no" votes in the Security Council are rare compared to affirmative votes, largely because of vote trading, and general pressures before an actual vote is taken, as will be discussed later on in this article. In addition to this, if a negative outcome of a vote is likely, the issue is usually not even voted on. We thank an anonymous reviewer for emphasizing this issue. In order to partially depart from the baseline assumption inherent in approaches based on the ICC principle, our paper also provides assessments for the situation in which votes cast by some members of the UN Security Council are in fact correlated. In future work, it might be fruitful to also test effects on institutional inertia and power distributions among actors when the probabilities of actors voting "yes" or "no" are adapted based on empirical insights. Whereas such extensions are very fruitful, evidently, care has to be applied assuming that observed empirical patterns in the past might be guidelines for preference distributions and voting behavior of actors in the future.
} 
but perhaps less so if we recall that the purpose of power indices is to evaluate the voting rule itself, abstracting from the preferences, behaviors and strategies that the voters (committee members) may have. Independence is a rational assumption in the absence of prior knowledge about the future issues to be voted upon and about how divided over these issues voters will be. It therefore suits the purpose of measuring the distribution of a priori or constitutional voting power that follows from the rules of the institution. Moreover, restraining assumed coalition-formation to specific patterns of preference similarity among like-minded states entails other risks: patterns of cooperation and coalition-formation among members are likely to change over time and members may form different coalitions depending on the specific issues at hand.

In case of the Penrose-Banzhaf-Coleman measures, we can check the robustness of our power calculations by integrating empirical observations - correlations between votes - into the analysis. To this end, we analyze voting behavior of the P-5 in the framework of another, related institution: the UN General Assembly. We construct a joint probability distribution of affirmative votes, taking into account correlations between the votes cast by the members of the P-5 (background to and results of this analysis are given in the appendix to this article).

Specifically, to assess voting power and decision probability in the Security Council, we assume that votes cast by the P-5 are correlated (as estimated on the basis of empirical voting records for the 1946 to 2002 time frame). In addition, as the composition of non-permanent members of the Security Council changes on a yearly basis, we assume that the votes of the non-permanent members are not correlated, but rather independent of each other, and similarly, independent of the permanent members' votes. We continue to assume, however, that for all member states - permanent and non-permanent ones-Ayes and Nays (Yes and No votes) occur with equal probabilities. Thus we maintain some degree of a priori-ness concerning voting by the P-5, but full a priori-ness for the non-permanent members of the Security Council, as the latter change over time by being elected to these temporary memberships.

It is important to emphasize, however, that the effect of the voting rule on the voting power of an individual member, or the power of a collectivity to act, is distinct from the effect of the joint probability distribution (Laruelle and Valenciano 2005, Kaniovski 2008). Coalitions that are winning under equally probable and independent votes continue to be winning when the votes lose either property. The only thing that changes is the probabilities of their occurrence. Put differently, the effects of voting rules and voting behaviors on voting power are separable, except when the vote is taken on the voting rule itself. It is the joint probability distribution that conveys something about the preferences and strategies of the voters (committee members). Clearly, states can anticipate the fact that they may, in general terms, be closer to the priorities of some UNSC permanent members than others. This will also influence their preference for one or several of the main reform proposals, as some new states would then be in the group of permanent members - states that can constitute friends or rather opponents in regional or global politics. Such considerations also influence, for example, the evaluation of Pakistan of the reform proposal by the Group of Four-which suggests having India as one of the new permanent UNSC members - or the preference of Argentina, who is unlikely to be 
unambiguously positive about the prospect of having Brazil be a permanent member of the Security Council. In this sense, rivalries among states within regions will matter as regards their priorities for Council reform, and UN member states will anticipate that proposals, although generating similar mean scores for non-permanent as compared to permanent members, will nonetheless differently empower or weaken particular states.

Our robustness check shows, however, that for the past and current configurations of the Security Council, and in fact for all potential Security Council reform scenarios, the discrepancies incurred in estimates of decision probability (and hence also voting power) due to the assumption of correlations among the votes of the P-5, are negligibly small. There are two rather surprising reasons for this. First, the correlations between votes cast by the P-5 are quite balanced in the sense that we observe clear US-UK-France and Russia-China probabilistic blocs. Positive correlation within the US-UK-France bloc, coupled with negative correlations of these votes with the votes of Russia and China, render the net effect on the joint probability distribution, and hence also on voting power measures, small. Second, the fact that there are more (in some reform scenarios even significantly more) nonpermanent members than permanent members in the Security Council makes the effect of any correlation among the P-5 on the joint probability distribution of all votes rather small.

In formal terms, we proceed as follows. Let $\mathbf{V}$ be the set of all coalitions, and $\mathbf{W} \subseteq$ $\mathbf{V}$ be the subset of winning coalitions. The Coleman measure is given by:

$$
P(\text { motion is passed })=\lambda=\frac{\# \mathbf{W}}{2^{n}} \text {. }
$$

In Eq. (1), $\# \mathbf{W}$ denotes the number of winning coalitions (the cardinality of the set W) that can form among committee members, and $1 / 2^{n}$ the probability of each conceivable coalition under the ICC principle.

In general, the probability of the voting body passing a motion depends on the preferences and the voting behavior of its members, as well as the voting rules. Over a large number of decisions, these complex factors are likely to be reflected in the probabilities of coalition-formation: some coalitions will be more likely to form than others. To derive a generalized version of the Coleman measure of the capacity of a collectivity to act, we may calculate Eq. 2:

$$
P(\text { motion is passed })=\sum_{\mathbf{v} \in \mathbf{V} \cap \mathbf{W}} \pi_{\mathbf{v}}
$$

Where $\pi_{\mathbf{v}}$ is the probability of coalition $\mathbf{v} \in \mathbf{V}$. In the case of equally probable and independent votes, the generalized measure given in Eq. 2 reduces to the one given in Eq. 1. In this case, all summands in Eq. 2 are equal, as $\pi_{\mathbf{v}}=1 / 2^{n}$, so that the probability of passing a motion can simply be expressed in terms of the total number of winning coalitions $\# \mathbf{W}$, as in Eq. 1.

In general terms, decision-making with a decision threshold higher than the simple majority clause, and with increasing membership, faces increasingly steeper hurdles. This is probably part of the reason for the pessimism on the part of several commentators regarding the prospects for UN Charter reform (Russett, 2005 and Sutterlin, 2005), as Charter reform requires affirmative votes of two- 
thirds of the membership of the UN General Assembly, including the concurrent votes of the P-5.

To analyze the UN Security Council, in which the P-5 hold veto power, and to assess the respective distribution of power within this institution, a weighted voting game can be constructed on the basis of linear extension. Subsequently, the scenario will be explored in which a coalition in the Security Council is only winning-i.e., can only make a resolution pass - when it contains the affirmative votes of all permanent members. ${ }^{4}$ Therefore, for simplicity, we do not account for the possibility of abstention by members of the P-5.

According to this assessment, in the Security Council, in the first constellation of UN membership, seven affirmative votes were needed to reach the required decision threshold. Since 1965, the respective requirement has been nine affirmative votes. ${ }^{5}$ In order to calculate effects with the methodological tools presented above, for the Security Council, a weighted voting game must be constructed that accounts for the possibility that member states use their veto power. In addition, the game has to account for the fact that no coalition in the Security Council can reach the decision threshold unless it is supported by all members of the P-5.

For the Security Council prior to the 1965 amendment, this weighted voting game is given by $[27 ; 5,5,5,5,5,1,1,1,1,1,1]$. Since 1965 , weighted voting in the Security Council can be represented by $[39 ; 7,7,7,7,7,1,1,1,1,1,1,1,1,1,1]$. Hence, the weights for the permanent members and the quota are chosen in such a way that the concurring votes (here interpreted as affirmative votes) of all permanent members are needed to form a winning coalition.

\section{Distribution of Power and Capacity to Act: Estimates for the Security Council}

How have this decision rule, and the attribution of veto power to the P-5, affected UN member states' leverage and collective decision probability within the Security Council? First, we will assess the baseline scenario based on the ICC assumption. Table 1 presents the respective results.

In the past and current configurations of Security Council membership, the (normalized) Banzhaf index indicates a clear asymmetry in favor of the P-5. O'Neill's slightly controversial assertion that actual power rests solely with the permanent members of the Security Council (O’Neill 1997) is hence corroborated by these power indices. In addition, respective figures on decision probability indicate that the probability of forming a winning coalition, within the current Security Council, is rather low (including less than $3 \%$ of all possible coalitions among members). ${ }^{6}$ In practice, decision probability may be higher, as votes may be aligned on specific dimensions on which the Security Council takes decisions. Nonetheless, this 'baseline

\footnotetext{
${ }^{4}$ Formally, player $\mathrm{i}$ has veto power if $\mathrm{i} \cap \mathrm{W}^{\mathrm{min}}$, i.e., if it is a member of every (minimum) winning coalition (e.g., see Van Deemen 1989: 318-19).

${ }^{5}$ Shapley and Shubik (1954) provide respective calculations with their 'own' index, the Shapley-Shubik index, for the first constellation of UN membership. Figures for both constellations of the Security Council, based on the Shapley-Shubik index, are provided, for example, in Ordeshook (1986: 467-68). See also Taylor and Zwicker (1993).

${ }^{6}$ The appendix to this paper shows that the assessments of the capacity to act are also valid if the assumption of correlated votes is introduced.
} 
Table 1 Voting power and decision probability in the UN Security Council, 1945 to present (Normalized Penrose-Banzhaf Index)

\begin{tabular}{lll}
\hline Member Category & $1945-1965$ & 1965 -present \\
\hline Permanent members: & & 16.69 \\
China & 18.10 & 16.69 \\
France & 18.10 & 16.69 \\
Russia & 18.10 & 16.69 \\
United Kingdom & 18.10 & 16.69 \\
United States & 18.10 & 83.46 \\
Total permanent members & 90.48 & 1.65 \\
Non-permanent members: & & 16.54 (10 members) \\
Voting power for each individual member & 1.59 & 2.59 \\
Total non-permanent members & $9.52(6$ members) \\
Decision probability & 2.78 & $-6.83 \%$ \\
$\quad$ Coleman's index of the power of a collectivity to act) & & \\
Change in action probability compared to 1945-1965 & - & \\
\hline
\end{tabular}

a) Formerly the U.S.S.R.

scenario' provides some interesting insights concerning the general difficulty for the Security Council to act, notably as the P-5 can block decisions with individual vetoes.

Of course, relative (formal) voting power is not the only factor affecting a member state's leverage in the Security Council. Political power and strategies such as threats or side-payments are important in practice to gain the support of other members on specific issues (or to at least induce them to abstain from voting). ${ }^{7}$ But institutional voting power matters even if a formal vote is not resorted to: voting power can influence member states' bargaining behavior due to the common knowledge, for example, that members can use their veto. Such patterns of formal power certainly affect even the many informal discussions conducted among Security Council members. It is the interaction between formal and more informal patterns of bargaining and voting that actually shape decision-making by the UN Security Council.

In practice, for long time spans in the history of the UN, some permanent members of the Security Council had a higher propensity to vote in agreement with other permanent members. For example, the United States was in a particularly powerful position in the first decades of the UN, since its views were generally shared with its allies in the Security Council, notably the United Kingdom and France. By comparison, in early phases of the UN, the U.S.S.R. was frequently isolated. More recently, however, western states, and notably the United States, have been forced to use their veto more often. ${ }^{8}$

\footnotetext{
${ }^{7}$ On voting in the Security Council and side-payments, see for example Kuziemko and Werker (2006).

${ }^{8}$ See Russett et al. (1997: 69): "The United States did not find it necessary to use the veto before 1970 since, until then, it could rally enough support from others to prevent a resolution that it opposed from coming to a vote. During this same period, the U.S.S.R. had to use the veto 105 times, because it was isolated and only through the veto could it prevent the adoption of resolutions that were contrary to its interests. Since 1970, however, the United States has made use of the veto seventy times and the U.S.S.R./ Russian Federation only nineteen times, reflecting very clearly the relationship between the value of the veto and the degree of isolation of a permanent member on substantive issues."
} 
Increased UN membership, largely as a result of the de-colonization process, has influenced power realities in the UN. Similarly, shifts in the geopolitical structure, notably the relative decline in global influence of some of the victors of World War II, the dissolution of the U.S.S.R., and the rise of new powers in the developing world, have changed the global distribution of power in comparison to the immediate post-war era. Many of the current criticisms of the Security Council and debates about reform, centre on these developments, and have raised the following points of concern: that those who contribute heavily to the upkeep of the UN and its programs, specifically Japan and Germany, are not included as permanent members; that there is no permanent seat (let alone veto power) for any representative of the Southern hemisphere; that of the entire Security Council's membership, 46\% are European (or European-associated), although they represent a mere $20 \%$ of the world's population; and finally, and perhaps most importantly, the Council no longer consists of those countries most capable of maintaining international peace and security, as the founders intended (Russett et al. 1997: 156-7).

In view of such perceived inequities, some recent suggestions for Security Council reform have focused on one of the following options (or a combination thereof): (1) abolishing veto power in the Security Council; (2) accepting more permanent members to the Security Council (e.g., Germany, Japan, India, Brazil or Nigeria); (3) enlarging Security Council membership by increasing the number of non-permanent members.

Questions of fairness and the quest for more legitimacy for the Security Council in world politics remain the drivers of reform. For example, according to a representative of Cameroon, "there is a pattern of behavior that is shared by the members of the Council, who, willingly or not, are often tempted to believe that agreement between five is the same as agreement between $15 \ldots$ little by little, it is becoming a body of five plus ten members" (Mahbubani, 2004: 253).

Clearly, more factors than mere veto rights influence actual power in the Security Council. For example, the 'Cyprusization' effect refers to the existence of a longstanding issue, where deliberations have been made over the years in which many of the non-permanent members have not been involved. In other words, only the P-5 can effectively address these issues, since they have been integrated in the respective discussions before: they have a continuous record of what has been discussed over the years and in the context of informal consultations, and possess superior information over other members.

In addition to the formal right of veto, another relevant aspect of power is that of the 'hidden veto', a phrase coined by Céline Nahory (Nahory, 2004). While the use of the veto has decreased since the end of the Cold War, the impact and the frequency of informal consultations within the Security Council appear to have increased. The quiet threat of the possible use of a veto is now applied behind closed doors. ${ }^{9}$ Consequently, the wording of a resolution can be weakened by the hidden veto of the P-5. An example of this was the draft resolution presented in 2004 by France

\footnotetext{
9 "By giving private veto warnings before a veto takes place, the P5 can 'convince' Council members to shift their position and still persuade the international public of their good intentions...Away from the public and without any record of what has been said, the P5 have more freedom to pressure, threaten, and even bully other members of the Security Council." (Nahory 2004: 1).
} 
regarding the protection of children in armed conflict (Resolution 1539), the text of which was based on a report of the Secretary General that provided a list of affected countries. The United Kingdom and Russia opposed the draft resolution because both Chechnya and Northern Ireland were included in the list, and hence, would be monitored if the resolution were to pass. During the so-called closed-door talks, however, the wording was changed from 'armed conflicts' to 'situations of concern', which enabled the Security Council to unanimously adopt the resolution.

This 'hidden veto' is also important in the context of agenda-setting. It is not possible to cast a veto regarding procedural matters, but threatening to use the veto may result in the withdrawal of an issue from the agenda. There may also be a 'double hidden veto' in the sense that non-permanent members choose not to address topics on which they suspect a hidden veto is likely to be applied. Clearly, these informal patterns affect the more formal rules of voting in the Security Council. However, the formal rules also structure the opportunities and constraints for patterns of informal negotiations.

Reflecting about options for a change of the formal rules of decision-making in this institution, the notion of 'fairness' has dominated discussions on Security Council reform. Should the council represent the nuclear powers of the world? Should it give a voice to the main economic actors and major contributors to the UN budget (e.g., Japan and Germany)? Or should the qualifying criterion be that the Security Council represent a majority of the world's population and its regional powers (motivating the membership of countries such as India, Brazil or Nigeria)?

Recent suggestions for reform have mainly been aimed at enlarging the Security Council and rendering it more representative of overall UN membership, without, however, compromising its relatively new-found organizational efficiency. For example, the Secretary-General's High-level Panel on Threats, Challenges and Change (2004) emphasized four main aspects regarding possible Security Council reform: a) honoring of Article 23 of the UN Charter by increasing the involvement in decision-making of those who contribute most to the UN financially, militarily and diplomatically; b) bringing into the decision-making processes countries more representative of the broader UN membership, especially of the developing world; c) avoiding impairing the Council's effectiveness; d) increasing the democratic and accountable nature of the Security Council.

Due to the diverse nature of UN membership, common notions of fairness or shared values are hard to come by. In combination with the high institutional hurdle for change, adapting the composition of the Security Council therefore constitutes a considerable challenge and explains why there appears to be seemingly endless debate on Security Council reform. Various proposals have been put forward over time to adapt the constellation of Security Council membership, but none has yet found backing by the required majority in the General Assembly. Recent efforts on this issue have started again in June 2010 in the framework of informal discussions on Security Council reform within the UN General Assembly.

The reform suggestion that came the closest to approval in the most recent years was from the Group of Four-Japan, Brazil, Germany and India - that aimed to expand the Security Council to a total membership of 25, by adding six permanent seats without veto power and four non-permanent seats. The G-4 agreed to provide Africa with two permanent seats in the Security Council (also without veto power). 
However, the African Union declined this suggestion in the summer of 2005, as it aspires to obtain two seats for Africa with veto power. Further opposition came in August 2005, from the new U.S. Ambassador, in cooperation with China, who opposed the plan, claiming that the suggested formula is divisive regarding the unity of every UN regional group.

Using the tools described above, calculations will be presented in this article showing the effects on relative voting power and decision probability if some fairly recent reform proposals were to be implemented. Two scenarios studied are based on suggestions made by the Secretary-General's High-level Panel on Threats, Challenges and Change (2004). As there is much discussion on the possible 'phasing out' of vetoes ${ }^{10}$ - which would provide all Security Council members with equal voting leverage - a further suggestion studied is the abolition of veto power. ${ }^{11}$ An earlier, more temperate proposal from Russett et al. (1997), aiming to increase non-permanent Council membership, will be presented along with its anticipated effects.

The High-level panel report made two major recommendations for reform with respect to voting and representation in the Security Council, providing proof of the difficulty in getting people to reach a consensus on this contentious issue. According to one scenario (Model A), six new permanent seats would be introduced, without adding new vetoes. Two of these seats would go to the regional area of Africa, two to Asia and the Pacific, one to Europe and one to the Americas. In addition, three new two-year term seats would be established. The ten current and three new nonpermanent seats would be allocated to regional areas as follows: Africa (4), Asia and Pacific (3), Europe (1) and Americas (4). The second scenario (Model B) did not call for the creation of any new permanent seats, but proposed the establishment of a new category of eight four-year renewable-term seats as well as one new two-year nonpermanent (and non-renewable) seat. In each case, there would be a total of six seatspermanent or non-permanent ones - for each geographical region.

Both proposals call for a Security Council in which five members hold veto power. Figures in these models are different, however, regarding the total number of four-year term non-permanent seats (ten according to the first proposal, eighteen in total according to the second one). Also, the first proposal recommends introducing three two-year term non-permanent seats, whereas only one such seat would be added according to the second proposal.

Reactions to the above proposals have been mixed (Zedillo, 2005). Whereas the proposals clearly are efforts aiming to implement improvements over the current situation and to be feasible in political terms, Sutterlin bemoans the usefulness of some of the suggestions for change, and is even more outspoken regarding the low likelihood of success and therefore urges that the entire subject of Charter reform be 'dropped', so

\footnotetext{
${ }^{10}$ The abolition of the veto has also been favored by prominent observers. E.g., see Tinbergen (1991: 4).

11 The Secretary-General's High-level Panel on Threats, Challenges and Change (2004), although it suggested two different models, was essentially also in favor of abolishing veto power. See paragraph 255 of the report: "Neither model involves any expansion of the veto or any Charter modification of the Security Council's existing powers. We recognize that the veto had an important function in reassuring the United Nation's most powerful members that their interests would be safeguarded. We see no practical way of changing the existing members' veto powers. Yet, as a whole the institution of the veto has an anachronistic character that is unsuitable for the institution in an increasingly democratic age and we would urge that its use be limited to matters where vital interests are genuinely at stake."
} 
as to prevent "further disharmony among states" (2005: 180). In contrast, Urquhart is slightly more optimistic, but sees the need for UN reform to become part of the agendas of high-level diplomats, as opposed to "junior diplomats in the committees of the General Assembly" (2005: 185). Similarly, Voeten urges that negotiations on UN reform shift from the confines of UN headquarters in New York and receive more attention at bilateral and multilateral summits, where trade-offs and bargaining are common and often provide solutions to apparent impasses (2005: 191). In contrast, Russett sees a danger in risking UN reform and watching it fail, and therefore suggests focusing on the other aspects of the High-Level Panel's report, such as terrorism and human rights, while leaving the UN Charter unchanged (2005: 153-66).

The slightly more radical suggestion, which can be found, for example, in Van Herpen (2003), essentially argues for adding Germany and Japan as new permanent members, re-balancing the Security Council by having more representatives of the southern hemisphere join as permanent members and finally, abolishing veto power in order to avoid power bias in favor of the P-5. Voeten, however, considers it unwise to include any changes to the veto in proposals to reform the Charter (2005: 195). Similarly, Russett et al. (1997) believe the retention of present veto rights is a necessary evil if the reform process is to succeed, and focus on the expansion of non-permanent membership (from 10 to 16) and allowing for re-election to some of those seats. Nonetheless, they acknowledge the inequities that are perpetuated by the veto, and suggest that its scope be curtailed to matters involving the "vital interests of the great powers", i.e., the P-5, as was intended by the founders of the organization. They also suggest increasing the voting threshold to 13 or 14 of the 21 member Council, thus further strengthening the collective position of non-permanent members. Indeed the latter option (threshold of 14) would give the 16 non-P-5 states a form of collective veto, as the passing of any decisions would require an almost two-thirds majority of their number. Finally, in the case that reform is successful, they call for a resolution that would institute regular reviews of Council voting rules and representation, so as to prevent the institution from falling into such an archaic trap again in the future (1997: 166-69).

In order to assess the respective effects of these proposals in both collective and distributive terms, weighted voting games need to be constructed. It is assumed that the decision threshold will again be approximately $60 \%$ of the total in each scenario (as $7 / 12=0.583$ and $9 / 15=0.6$ ). Proposals $\mathrm{A}$ and $\mathrm{B}$ can then be captured by the game $[64 ; 11,11,11,11,11,1,1,1,1,1,1,1,1,1,1,1,1,1,1,1,1,1,1,1]$, where the five permanent members with veto power can only get a resolution passed if nine other Security Council members agree with the proposal (with a total of 14 affirmative votes being required, or a fraction of $14 / 24=0.583$ ). However, each member with veto power is needed for the formation of a winning coalition, as the votes of the nineteen members without veto power, in addition to the affirmative vote of four permanent members with vetoes, would not suffice to form a winning coalition (as 19 plus 44 is 63, i.e., one vote short of the decision threshold of 64 votes).

Table 2 shows the respective calculations in terms of a priori voting power and decision probability for the proposals of the High-Level Panel. ${ }^{12}$

\footnotetext{
$\overline{{ }^{12}}$ For the analysis of earlier proposals regarding changes in the composition of the Security Council also see Wallensteen (1994) or Burrell (1995).
} 
Table 2 Voting power and decision probability in an enlarged UN Security Council: suggestions of the High-level Panel (Models A and B, Penrose-Banzhaf Index)

\begin{tabular}{|c|c|c|}
\hline Proposal & High-Level Panel, Model A & High-Level Panel, Model B \\
\hline \multirow[t]{3}{*}{ Adaptations } & six new permanent seats & no new permanent seats \\
\hline & no creation of new vetoes & $\begin{array}{l}\text { creation of a new category of } \\
\text { eight four-year renewable-term } \\
\text { seats }\end{array}$ \\
\hline & $\begin{array}{l}\text { three new two-year term } \\
\text { seats on basis of regional } \\
\text { allocation }\end{array}$ & $\begin{array}{l}\text { one new two-year } \\
\text { non-permanent } \\
\text { (and non-renewable) seat }\end{array}$ \\
\hline Permanent seats & 11 (5 with veto power) & 5 \\
\hline Non-permanent seats (four-year term) & - & 8 \\
\hline Non-permanent seats (two-year term) & 13 & 11 \\
\hline Individual voting power: & $\begin{array}{l}24 \text { members, } 5 \text { with veto } \\
\text { power }\end{array}$ & 24 members, 5 with veto power \\
\hline Permanent SC members with vetoes & 13.62 & 13.62 \\
\hline $\begin{array}{l}\text { Permanent SC members without } \\
\text { vetoes and non-permanent members } \\
\text { of the SC }\end{array}$ & 1.68 & 1.68 \\
\hline \multicolumn{3}{|l|}{ Collective power: } \\
\hline $\begin{array}{l}\text { Permanent SC members with vetoes } \\
(5 \text { members })\end{array}$ & 68.07 & 68.07 \\
\hline $\begin{array}{l}\text { Permanent members without vetoes } \\
\text { (6 members) and non-permanent SC } \\
\text { members ( } 13 \text { members })\end{array}$ & 31.93 & 31.93 \\
\hline $\begin{array}{l}\text { Decision probability (Coleman's index } \\
\text { of the power of a collectivity to act) }\end{array}$ & 2.11 & 2.11 \\
\hline $\begin{array}{l}\text { Change in action probability compared } \\
\text { to status quo }\end{array}$ & $-18.5 \%$ & $-18.5 \%$ \\
\hline
\end{tabular}

According to the suggestions for reform incorporated into the report of the High-level panel, decision probability, at just above $2 \%$, would decrease by $18.5 \%$ compared to the status quo. In distributive terms, a priori voting power would remain fairly constant, compared to the current situation (see Table 1), when assessed individually, for permanent members with veto power, permanent members without vetoes, and nonpermanent members of the Security Council. Individual power is about $14 \%$ for permanent members with veto power according to the normalized Penrose-Banzhaf index, whereas new permanent members without vetoes and non-permanent members, in these scenarios, would each hold $1.7 \%$ of a priori power. Permanent members would lose little relative influence by increasing Security Council membership. Considered by groups, assessments are 68\% (normalized Penrose-Banzhaf index) for the collectivity of permanent members and about 32\% (normalized Penrose-Banzhaf index) for the non-permanent members evaluated as a group.

In order to assess the distributive effects of the proposal by Russett, O'Neill and Sutterlin (1997), we must again construct a weighted voting game. There are two options in the proposals set forward: both would maintain the size and vetoentitlements of the P-5, but would add 6 non-permanent seats; both would allow for 
reelection to some of the 16 non-permanent seats; but on the subject of the new voting threshold they would allow for two options of 13 or 14 of the 21 Council members. Thus, the weighted voting games are as follows: [53; $9,9,9,9,9,1,1,1,1,1,1,1,1,1,1,1,1,1,1,1,1]$ represents the proposal with an action threshold of 13 , while $[54 ; 9,9,9,9,9,1,1,1,1,1,1,1,1,1,1,1,1,1,1,1,1]$ accounts for a threshold of 14 .

Table 3, in columns one and two, shows the projected effects of both the Van Herpen (2003) proposal to abolish vetoes, as well as the proposal put forward by Russett, O'Neill and Sutterlin (1997).

The proposal to abolish vetoes would strongly increase decision probability in the Council to more than $27 \%$, given the vastly increased number of possible winning coalitions. Compared to the status quo, this amounts to a change in action probability of close to $950 \%$. It would also reduce the a priori voting power of individual permanent members to just above $4 \%$ of the total. The balance of collective influence between permanent and non-permanent members, according to either index, would then be about $58 \%$ as compared to $42 \%$. Hence, the latter proposal would generate the strongest re-balancing of power between the P-5 and non-permanent members, and would considerably increase decision probability within the Security Council.

The effects of the Russett, O'Neill and Sutterlin proposal on voting power also improve the lot of non-permanent members, vis-à-vis their P-5 counterparts however, not as markedly as the previous case according to the Shapley-Shubik Index. ${ }^{13}$ With an action threshold of 13 out of 21 members (62\%), the collective voting power of the non-permanent section of the Council is double of what it is today, and the Penrose-Banzhaf Index records a similar doubling. This trend is even more apparent when the action threshold of 14 is introduced (66\%): in terms of the Penrose-Banzhaf Index, individual voting power for the P-5 shrinks from $16.7 \%$ in today's Council configuration to a 'mere' $11.2 \%$, while the Shapley-Shubik Index notes a similar, if less emphatic, downward trend. Collective voting power for the non-permanent 16 members of the Council improves almost threefold according to both the Penrose-Banzhaf and Shapley-Shubik assessments. Naturally, these improved figures entail some sort of trade-off, and the drawback, in this case, is a decline in decision probability, which is reduced from the current $2.6 \%$ to 1.9 and $1.3 \%$ respectively. A further effect of this proposal, which is not accounted for in the calculations, is the narrowing of the scope of the veto. The above indices indicate the distributive effects on decision-making when vetoes apply. However, for all other forms of decision-making, such as election of the Secretary General, and admission of new members, the voting power in the Security Council would resemble Van Herpen's suggestions, i.e., there would be parity among individual members.

Another proposal was tabled by the Group of Four and aimed to enlarge the council by six new permanent seats without veto, and four non-permanent seats. Similarly, the African Union suggested expanding the council by adding six permanent seats with veto power, and five non-permanent seats. Finally, a proposal tabled by a group of about twenty countries, labeled 'Uniting for Consensus' suggests expanding the council to twenty-five members, but with ten new rotating non-permanent seats. Again, respective

${ }^{13}$ See respective figures for the Shapley-Shubik index in the online appendix. 


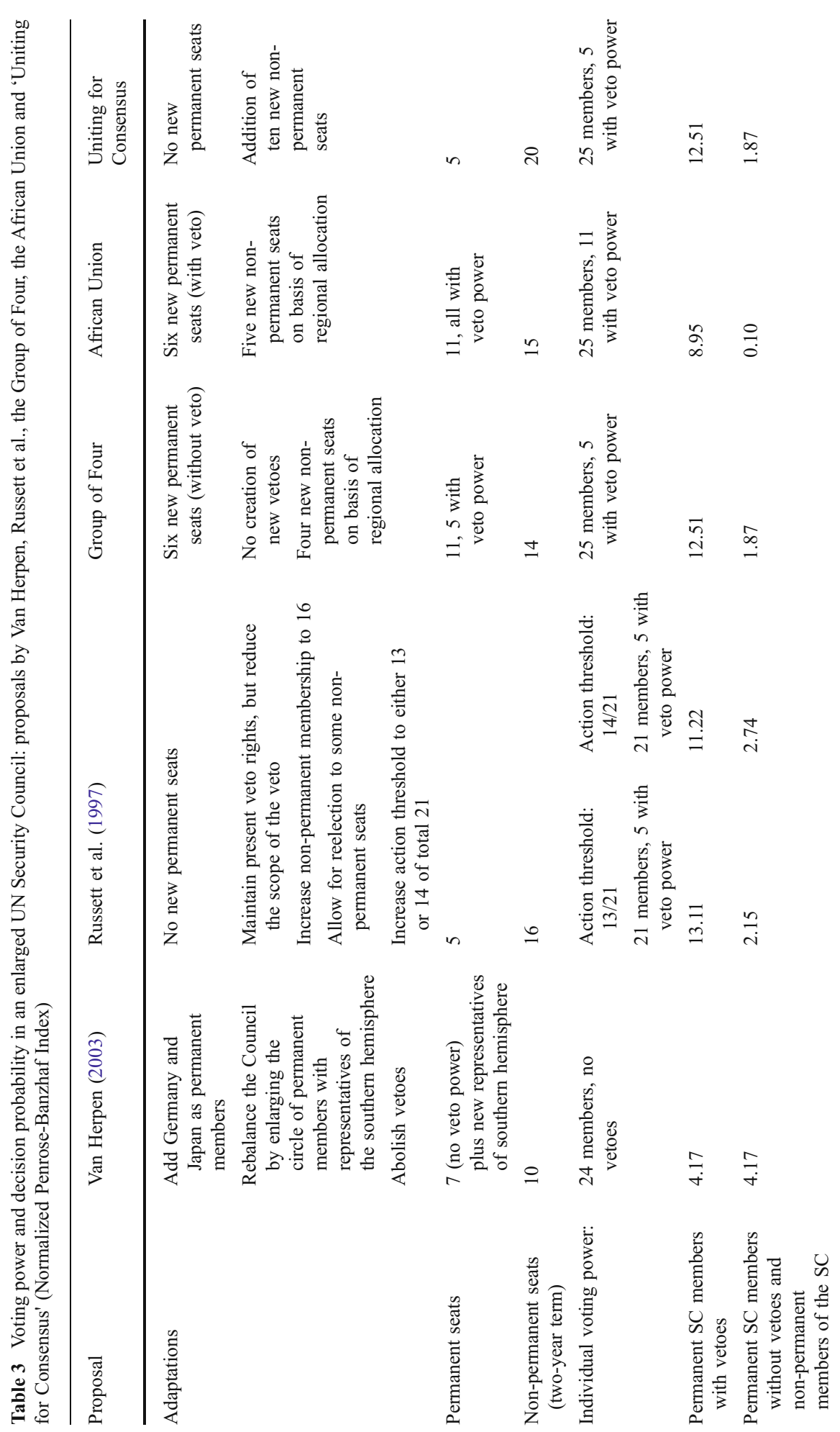




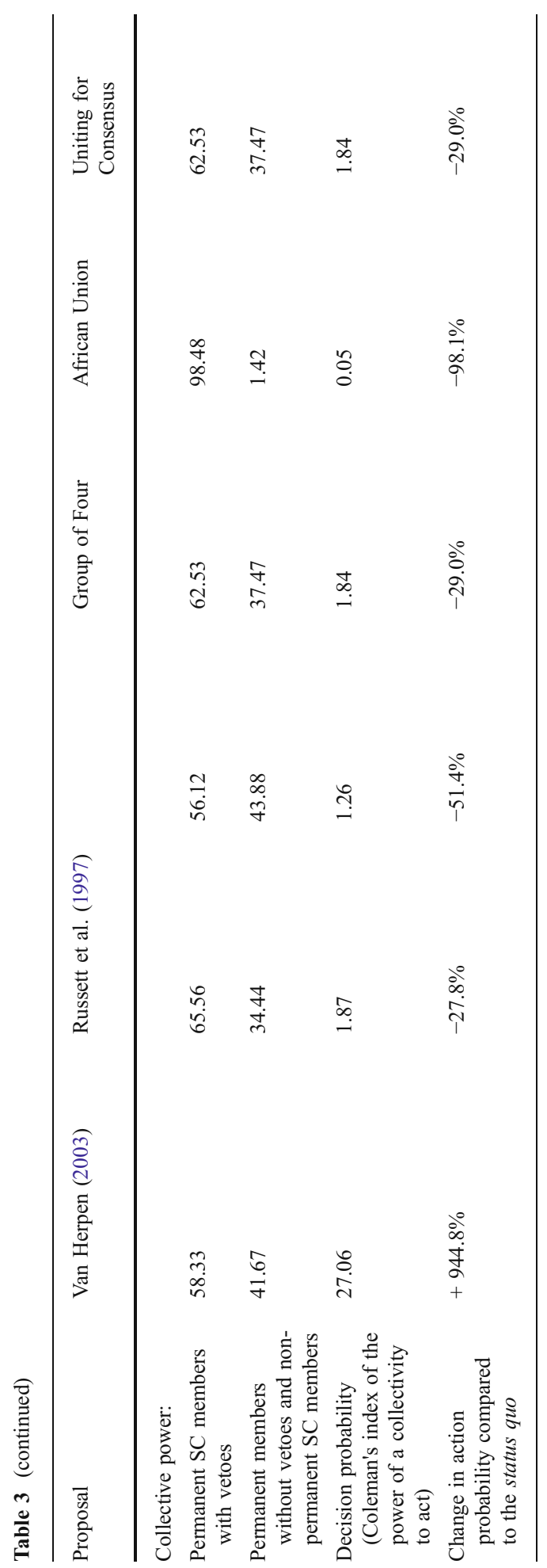


voting games with vetoes have to be constructed to assess effects of these models. ${ }^{14}$ This proposal suggests making decisions on the basis of the simple majority rule, and constraining the use of the veto.

Columns three, four and five of Table 3 provide an overview of the repercussions of these suggestions in terms of both collective and distributive effects. The proposals of the Group of Four and of 'Uniting for Consensus' are, although initiated largely in opposition to each other, similar in terms of overall distributive effects, at least when analyzing their institutional 'skeleton' (i.e., without specific country labels attached to the new seats to be attributed). However, the Uniting for Consensus proposal aspires to introduce simple majority voting. In these models, power distributions between members with and without veto power are similar to the two models proposed by the High-level Panel. Similarly, decision probability, due to the formal maintenance of the veto for the P-5 (although veto use would be restricted) without the addition of new vetoes, would remain fairly constant, but still be lower (by about 30\%) compared to the status quo. By comparison, the model proposed by the African Union would spread veto power more evenly across regions, but would tilt the overall balance of power even more in the direction of Security Council members holding veto power. In addition, as would be expected, decision probability, as measured with Coleman's index of the power of a collectivity to act, would decrease quite strongly, to less than one-half percent. This constitutes a decrease of almost $100 \%$ compared to the status quo.

Ian Hurd (1997) argues that in the face of the present inability to achieve the much sought-after changes in the institutional structure of the UN-and specifically the Security Council - the organization should make the most of its flexibility, and use informal arenas to further involve those countries that deem themselves 'beyond the fringe'. He points to the example of resource-contributing countries, such as Germany and Japan, whose contacts and consultations with the Council have become institutionalized (Hurd, 1997). Indeed, he goes so far as to say that the case for adding formal members to the Council is 'scuppered', as non-member states have regular and well-established opportunities to participate in deliberation with the formal members on a variety of issues (2007: 22). Jochen Prantl (2005) adds further weight to this argument, similarly claiming that the informal arenas and modes of interaction in the UN are 'the way forward'.

\section{Conclusions}

The UN Security Council faces the challenge of institutional reform. Due to its membership and voting rules, which essentially reflect the now largely outdated power distribution that existed in international relations in the aftermath of World War II, there has been much debate for several years on reforming its constellation and adapting its voting procedures. Various proposals have been presented over time ranging from radical scenarios, which aim to abolish veto power, to more moderate-

\footnotetext{
${ }^{14}$ For the proposal of the Group of Four and for 'Uniting for Consensus', due to the fact that the number of permanent seats with vetoes is 5 for both proposals, the respective weighted voting game is $[65 ; 11,11$, $11,11,11,1,1,1,1,1,1,1,1,1,1,1,1,1,1,1,1,1,1,1,1]$; for the proposal by the African Union, it is $[136 ; 12,12,12,12,12,12,12,12,12,12,12,1,1,1,1,1,1,1,1,1,1]$.
} 
and more politically realistic - proposals, envisaging an expansion of the size of the Security Council, without, however, sacrificing decision probability.

The High-level panel on Threats, Challenges and Change (2004) made two main proposals to change the Security Council and in general terms, aimed to propose politically feasible solutions, by suggesting the maintenance of veto power for the P-5 and an expansion of the Council with a combination of permanent and non-permanent seats. This analysis has shown that these proposals would result in a moderate decrease in collective voting power for the P-5. The more idealistic reform proposal put forward by Van Herpen - including the abolition of the veto- has been shown to drastically alter the balance of voting power in the Council, as well as greatly increase decision probability beyond its present levels. Many argue that this is the only morally justifiable alternative, in terms of fairness as well as effectiveness. However, such radical suggestions can certainly be problematic in the context of global power politics and understandably, the P-5 are loathe to relinquish their right of veto.

A less recent proposal by Russett et al. (1997) focused heavily on what is desirable, but also achievable, deciding to retain the present veto rights, while increasing the non-permanent membership. The results were favorable in terms of rebalancing the Council and improving the position of non-permanent members. The Council's effectiveness, however, would appear to suffer, with a slight drop in decision probability. Their approach is quite pragmatic, and as a result, is one that could eventually make some progress in the current reforms impasse.

A recent proposal by the Group of Four-Brazil, Germany, India and Japan - to expand the council has found fairly widespread support, but failed in the summer of 2005 due to opposition by a range of countries, including Pakistan, Italy, China and the United States. Its distributive effects are similar to the proposals of the HighLevel Panel, and further increase the collective voting power of non-veto holders in the Council. However, there is a slight decrease in decision probability. Meanwhile, the calculated effects of the proposals made by the group 'Uniting for Consensus' are nearly identical to those of the Group of Four if the current decision threshold is maintained. A shift to simple majority voting, in this context, would increase decision probability and decrease the power of the P-5. The African Union itself proposed six new permanent and veto-carrying seats, which virtually obliterate any non-permanent, or non-veto countries' voting power. A further drawback is the large loss in decision probability as a result of their proposals. The aim to reach a compromise on Security Council reform by the fall of 2005 hence proved to be illusive, but discussions continue on an intensive scale about possible options for reform.

In current discussions, the diversity of preferences among UN member states regarding the modes to expand the Security Council and the specific states to be accepted as new permanent members is widely apparent. What seems to be far less clear, however, is that changing the Security Council was probably not an easy endeavor in the 1960s, but, due to the much higher number of UN member states, may have turned into an almost illusive enterprise today. As discussions on Security Council reform show, large membership of international organizations may freeze institutional provisions, making change much more difficult to effect. 
Clearly, finding a suitable package that has the potential to overcome the various institutional hurdles for change, and to reform the Security Council, constitutes a considerable challenge to the international community. Essentially, the developments and changes in geopolitics that have occurred since the Second World War make clear the need for urgent reform of the UN-particularly the Security Council—but it is the myriad of effects, brought on by precisely these changes, that renders the task of reform so arduous. However, the desirability of change can not be overlooked. Reform of the Security Council, if successful in spite of the high institutional hurdles to be taken and the broad divergence in member states' preferences, could contribute to rendering UN actions and patterns of global governance more legitimate and more effective in the future.

\section{Appendix}

Table A.1 gives Pearson product moment correlation coefficients between the votes of the five permanent members in the UN General Assembly between 1946 and 2002 (the source is roll call data assembled by Erik Voeten, George Washington University). To comply with the binary voting framework, we treat abstentions as No votes. The correlation coefficients between Yes and No/Abstain votes differ little from those between Yes and No votes. ${ }^{15}$

Next, we elaborate the procedure for constructing the joint probability distribution that is consistent with the above correlation matrix. In a voting body comprising $n$ members, let $p_{i} \in[0,1], i=1,2, \ldots, n$, denote the marginal probability of the $i$-th member voting in favor of a motion, and $c_{i, j} \in[-1,1], 1 \leq i<j \leq n$, denote the correlation coefficient between any two affirmative votes.

A voting profile is a binary vector $\mathbf{v}=\left(v_{1}, v_{2}, \ldots, v_{n}\right)$, whose $i$-th coordinate is $v_{i}=1$ if member $i$ votes affirmatively, and equals zero otherwise. Define $\mathbf{V}$ as the set of all voting profiles, and $\mathbf{V}(i)$ as the set of voting profiles in which member $i$ votes affirmatively (i.e., the set of all binary vectors $\mathbf{v}$ such that $v_{i}=1$ ). Moreover, define $\mathbf{V}$ $(i, j)=\mathbf{V}(i) \cap \mathbf{V}(j)$ as the set of voting profiles in which members $i$ and $j$ both vote affirmatively, i.e., the set of all binary vectors $\mathbf{v}$ such that $v_{i}=v_{j}=1$. Sets $\mathbf{V}, \mathbf{V}(i)$ and $\mathbf{V}(i, j)$ contain $2^{n}, 2^{n-1}$ and $2^{n-2}$ elements, respectively.

A joint probability distribution $\pi_{\mathbf{v}}$ on the set of voting profiles $\mathbf{V}$ must satisfy the following constraints, given marginal probabilities and correlation coefficients:

$$
\begin{gathered}
\pi_{\mathbf{v}} \geq 0 \text { for all } \mathbf{v} \in \mathbf{V} ; \\
\sum_{\mathbf{v} \in \mathbf{V}} \pi_{\mathbf{v}}=1 ;
\end{gathered}
$$

\footnotetext{
${ }^{15}$ Assessing votes pre-1990 and post-1990 separately reveals that correlations between the P-5 until 1990 very much resemble the pattern shown in Table A.1, but with the negative correlation between Russia and the U.S. being somewhat stronger $(\mathrm{r}=-0.50)$ and voting correlation between the U.S. and China being almost neutral $(r=-0.06)$. By comparison, for the post-1990 phase, the voting behavior of the UK and France is almost identical, with $r=0.92$ between their votes, whereas the correlation between the votes of Russia and the U.S. is moderately positive $(r=0.2)$. However, China and the U.S. tend to diverge quite often in the post-1990 phase, as $r=-0.50$, whereas the votes of China and Russia are hardly correlated in the post-1990 phase $(r=0.08)$.
} 
Table A.1 Correlations among the votes of the P-5 in the UN General Assembly

\begin{tabular}{llllll}
\hline & US & UK & FR & RU & CH \\
\hline US & 1 & & & & \\
UK & 0.611 & 1 & 1 & & \\
FR & 0.464 & 0.767 & -0.152 & 1 & \\
RU & -0.361 & -0.235 & -0.041 & 0.106 & 1 \\
CH & -0.230 & -0.093 & & & \\
\hline
\end{tabular}

Calculations based on UN General Assembly roll call data 1946 to 2002 (collected by Erik Voeten, George Washington University).

$$
\begin{gathered}
\sum_{\mathbf{v} \in \mathbf{V}(i)} \pi_{\mathbf{v}}=p_{i} \text { for all } i=1,2, \ldots, n \\
\sum_{\mathbf{v} \in \mathbf{V}(i, j)} \pi_{\mathbf{v}}=p_{i} p_{j}+c_{i, j} \sqrt{p_{i}\left(1-p_{i}\right) p_{j}\left(1-p_{j}\right)} \text { for all } 1 \leq i<j \leq n .
\end{gathered}
$$

The last equality follows from the definition of the correlation coefficient and the fact that the votes are Bernoulli random variables.

Geometrically, the set defined by constraints (A1)-(A4) is a convex polytope in a $2^{n}$ Euclidean space. Any point therein is a suitable distribution. Since the system (A2)-(A4) comprises $1+n+\frac{n(n-1)}{2}$ equations for $2^{n}$ unknowns, it will typically have infinitely many solutions for $n \geq 3$. We choose a particular distribution by imposing an additional criterion. Following Kaniovski (2008), we choose the distribution closest (using least squares) to the distribution in the case of independent votes. This is accomplished by solving the following quadratic optimization problem:

$$
\min _{\pi_{\mathbf{v} \in \mathbf{V}}} \frac{1}{2}\left[\sum_{\mathbf{v} \in \mathbf{V}} \pi_{\mathbf{v}}-\prod_{i=1}^{n} p_{i}^{v_{i}}\left(1-p_{i}\right)^{1-v_{i}}\right]^{2},
$$

subject to constraints (A1)-(A4). The product term represents the corresponding probability for independent votes. In full generality, the above quadratic optimization problem can only be solved numerically, although slightly less general problems have known analytical solutions.

Assuming $p_{i}=0.5$, for $i=1,2, \ldots, n$, and $c_{i, j}$ as obtained in the correlation matrix shown in Table A.1, leads to the distribution of the set of 32 conceivable voting profiles. Figure A.1 shows that the distribution implied by correlated votes is quite different from the 'uniform' distribution resulting from independent votes. The abscissa shows the 32 voting profiles sorted in descending order of the decimals the binary vector $\mathbf{v}$ represents. 

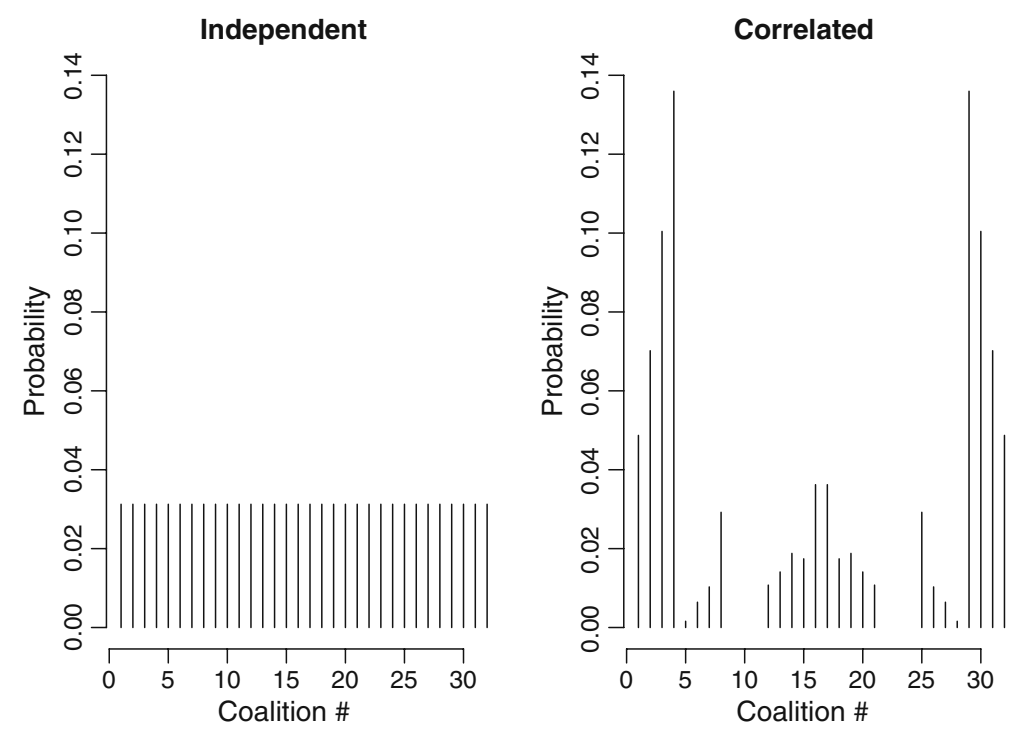

Fig. A.1 Joint probability distribution for independent as compared to correlated votes

Having obtained the probability distribution for the P-5, we can now embed this distribution in a much larger set of conceivable voting profiles that includes the Security Council's non-permanent members. Let the total number of members be $N$, of which $n, n \leq N$, members hold veto power (the US, UK, France, Russia and China). Assuming that non-permanent members vote independently with probability 0.5 , the joint probability distribution of $N$ votes is

$$
\pi_{\mathbf{v}}^{N}=\frac{\pi_{\mathbf{v}}}{2^{N-5}} \text { for all } \mathbf{v} \in \mathbf{V} .
$$

Substituted into the generalized Coleman measure, the probabilities given above generate the decision probabilities shown in Table A.2. Situations accounted for are the past and present constellation of the Security Council, the two alternative proposals contained in the report of the High-level Panel on Threats, Challenges and Change (2004) and finally, the proposal by Russett et al. (1997), with two different scenarios regarding the voting threshold.

A comparison of the adjusted calculations for the capacity of a collectivity to actbased on the assumption of partially correlated votes - with the standard Coleman index

Table A.2 Robustness of the Coleman measure to correlation

\begin{tabular}{|c|c|c|c|}
\hline & & Coleman & Adjusted Coleman \\
\hline Pre-1965 & & 0.0278 & 0.0265 \\
\hline Post-1965 & & 0.0259 & 0.0251 \\
\hline Proposal A and B & & 0.0211 & 0.0209 \\
\hline \multicolumn{4}{|c|}{ Proposal by Russett et al. (1997) } \\
\hline & threshold 13 & 0.0187 & 0.0185 \\
\hline & threshold 14 & 0.0126 & 0.0127 \\
\hline
\end{tabular}


(i.e., analogous probabilities computed under the independence assumption) reveals that the differences between the two assessments are small. Accordingly, measures assessing the capacity of a collectivity to act are robust when using the assumption of correlated votes among the P-5 (based on actual voting data) as compared to calculations based on the assumption that members cast votes independently. In extension, this will also be true for the Penrose-Banzhaf measure, as it uses the same probability space as the Coleman index of the capacity of a collectivity to act does.

Open Access This article is distributed under the terms of the Creative Commons Attribution Noncommercial License which permits any noncommercial use, distribution, and reproduction in any medium, provided the original author(s) and source are credited.

\section{References}

Baehr, P. R., \& Gordenker, L. (1999). The United Nations in the 1990s. London: Macmillan.

Bailey, S. D. (1969). Voting in the Security Council. Bloomington: Indiana University Press.

Banzhaf, J. F. (1965). Weighted Voting Doesn't Work. Rutgers Law Review, 19(2), 317-43.

Buchanan, J. M., \& Tullock, G. (1962). The Calculus of Consent. Ann Arbor: The University of Michigan.

Bueno de Mesquita, B., \& Alastair, S. (2010). The Pernicious Consequences of UN Security Council Membership, Journal of Conflict Resolution (forthcoming).

Burrell, D. (1995). "Reforms of the United Nations Security Council: The Impact on Member States' Voting Power" (mimeo).

Coleman, J. S. (1971). Control of Collectivities and the Power of a Collectivity to Act. In B. Lieberman (Ed.), Social Choice (pp. 269-300). New York: Gordon and Breach.

Dreher, A., Sturm, J.-E., \& Vreeland, J. (2009a). Development Aid and International Politics: Does Membership of the UN Security Council Influence World Bank Decisions? Journal of Development Economics, 88, 1-18.

Dreher, A., Sturm, J.-E., \& Vreeland, J. (2009b). Global Horse Trading: IMF Loans for Votes in the United Nations Security Council. European Economic Review, 53(7), 742-757.

Felsenthal, D. S., \& Machover, M. (1998). The Measurement of Voting Power: Theory and Practice. Cheltenham: Edward Elgar.

Hosli, M., \& Machover, M. (2004). The Nice Treaty and Voting Rules in the Council: A Reply to Moberg (2002). Journal of Common Market Studies, 42(3), 497-521.

Hurd, I. (1997). Security Council Reform: Informal Membership and Practice. In B. Russett (Ed.), The Once and Future Security Council (pp. 135-52). New York: St Martin's Press.

König, T., \& Bräuninger, T. (1997). The Inclusiveness of European Decision Rules. Journal of Theoretical Politics, 10, 125-42.

Kaniovski, S. (2008). The Exact Bias of the Banzhaf Measure of Power When Votes are Neither Equiprobable Nor Independent. Social Choice and Welfare, 31, 281-300.

Kuziemko, I., \& Werker, E. (2006). How much is a Seat on the Security Council Worth? Foreign Aid and Bribery at the United Nations. Journal of Political Economy, 114(5), 905-930.

Laruelle, A., \& Valenciano, F. (2005). Assessing Success and Decisiveness in Voting Situations. Social Choice and Welfare, 24, 171-197.

Leech, D. (2002a). Designing the Voting System for the EU Council of Ministers. Public Choice, 113(34), 437-464.

Leech, D. (2002b). An Empirical Comparison of the Performance of Classical Power Indices. Political Studies, 50, 1-22.

Mahbubani, K. (2004). The Permanent and Elected Council Members. In D. M. Malone (Ed.), The UN Security Council: From the Cold War to the $21^{\text {st }}$ Century. Boulder, CO: Lynne Rienner Publishers.

Nahory, C. (2004). "The Hidden Veto." Global Policy Forum, United Nations Security Council. Available at http://globalpolicy.igc.org/resource/pubs. 
O'Neill, B. (1997). Power and Satisfaction in the Security Council. In B. Russett (Ed.), The Once and Future Security Council (pp. 59-82). New York: St Martin's Press.

Ordeshook, P. C. (1986). Game Theory and Political Theory. An Introduction. Cambridge: Cambridge University Press.

Penrose, L. S. (1946). The Elementary Statistics of Majority Voting. Journal of the Royal Statistical Society, 109, 53-7.

Prantl, J. (2005). "Informal Groups of States and the UN Security Council," International Organization, 59 (Summer), pp. 559-92.

Rochester, J. M. (1993). Waiting for the Millennium: The United Nations and the Future of World Order. Columbia: University of South Carolina Press.

Russett, B. M., O'Neill, B., \& Sutterlin, J. S. (1997). Breaking the Restructuring Logjam. In B. Russett (Ed.), The Once and Future Security Council (pp. 153-72). New York: St Martin's Press.

Russett, B. (2005). Security Council Expansion: Can't, and Shouldn't. In E. Zedillo (Ed.), Reforming the United Nations for Peace and Security (pp. 153-66). New Haven, CT: Yale Centre for the Study of Globalization.

Secretary-General's High-level Panel on Threats, Challenges and Change (2004). A More Secure World: Our Shared Responsibility, New York: United Nations. Available at http://www.un.org/secureworld.

Shapley, L. S., \& Shubik, Martin. (1954). A Method of Evaluating the Distribution of Power in a Committee System. American Political Science Review, 48, 787-792.

Straffin, P. D. (1977). Homogeneity, Independence and Power Indices. Public Choice, 30, 107-118.

Sutterlin, J. S. (2005). Some Thoughts - Mostly Cautionary - on the Recommendations of the High-Level Panel on Threats, Challenges, and Change. In: Ernesto Zedillo (Ed.). Reforming the United Nations for Peace and Security (pp. 167-82). New Haven, CT: Yale Centre for the Study of Globalization.

Taylor, A. D. and Zwicker W. S. (1993). Weighted Voting, Multicameral Representation, and Power. Games and Economic Behavior, 5, 170-81.

Tinbergen, J. (1991). Supranational Decision-Making: A More Effective United Nations. Waging Peace Series, 29. Santa Barbara: Nuclear Age Peace Foundation.

Van Deemen, Ad M. A. (1989). Dominant Players and Minimum Size Coalitions. European Journal of Political Research, 17, 313-32.

Van Herpen, M. (2003). Security Council Reform: How and When? The National Interest, October 8. Available at http://nationalinterest.org/article/security-council-reform-how-and-when-2449.

Voeten, E. (2005). Some Comments on UN Charter Reform. In: Ernesto Zedillo (Ed.). Reforming the United Nations for Peace and Security (pp. 189-96). New Haven, CT: Yale Centre for the Study of Globalization.

Wallensteen, P. (1994). Representing the World. A Security Council for the 21st Century. Security Dialogue, 25(1), 63-75.

Zedillo, E. (2005). Overview. In: Ernesto Zedillo (Ed.). Reforming the United Nations for Peace and Security (pp. 1-18). New Haven, CT: Yale Centre for the Study of Globalization. 